\title{
A patient with esophageal achalasia and common variable immunodeficiency: A Case report and review of the literature
}

\author{
Paciente con acalasia esofágica e inmunodeficiencia común \\ variable. Reporte de caso y revisión bibliográfica
}

David Avelar-Rodríguez, ${ }^{1}$ Erick Manuel Toro-Monjaraz, ${ }^{1}$ Rubén Peña Vélez, ${ }^{1}$ Marco Antonio Yamazaki-Nakashimada, ${ }^{2}$ Jaime Alfonso Ramírez-Mayans ${ }^{1}$

\begin{abstract}
BACKGROUND: Esophageal achalasia is characterized by defective esophageal peristalsis and insufficient relaxation of the lower esophageal sphincter secondary to degeneration of the myenteric plexus. The exact pathophysiological mechanism through which the myenteric plexus is damaged is not fully understood, but increasing evidence suggests that autoimmunity may play a role. Patients with primary immunodeficiencies often develop autoimmunity, and recent studies have shown an increased prevalence of autoimmune diseases in patients with esophageal achalasia.

CLINICAL CASE: We present the case of an 18-year-old female with a history of common variable immunodeficiency and a high degree of autoimmunity (alopecia, vitiligo and autoimmune thyroiditis), who presented with rapidly progressive dysphagia, chest pain, and food regurgitation. A barium swallow and a high-resolution esophageal manometry were performed, and she was diagnosed with type III esophageal achalasia, the least common subtype $(10 \%)$.
\end{abstract}

CONCLUSION: Patients with primary immunodeficiencies often develop autoimmunity and may be at increased risk of developing esophageal achalasia. Further research is warranted in order to elucidate the role of autoimmunity in esophageal achalasia.

KEY WORDS: Esophageal achalasia; Esophageal peristalsis; Esophageal Sphincter; Deglutition Disorders; Immunodeficiency; Autoimmune.

Resumen

ANTECEDENTES: La acalasia esofágica se caracteriza por alteraciones en la persitalsis esofágica y relajación insuficiente del esfínter esofágico inferior, secundaria a la degeneración del plexo mientérico. Sigue sin conocerse el mecanismo fisiopatológico exacto por el que el plexo mientérico se daña; en la bibliografía se sugiere que la autoinmunidad puede jugar un papel decisivo. Con frecuencia, los pacientes con inmunodeficiencias primarias tienen autoinmunidad. Los estudios recientes demuestran que la prevalencia de autoinmunidad en pacientes con acalasia es elevada. CASO CLínICO: Paciente del sexo femenino, de 18 años, con antecedente de inmunodeficiencia común variable y autoinmunidad (alopecia, vitíligo y tiroiditis autoinmunitaria), con disfagia rápidamente progresiva, dolor de pecho y regurgitación. Con el reporte del esofagograma y la manometría esofágica de alta resolución se estableció el diagnóstico de acalasia tipo III, el subtipo menos común (10\%).

CONCLUSIÓN: Con frecuencia, los pacientes con inmunodeficiencias primarias resultan con autoinmunidad y pueden tener un riesgo elevado de padecer acalasia esofágica. Hacen falta más estudios para poder entender mejor la fisiopatología de la acalasia esofágica.

PALABRAS CLAVE: Acalasia esofágica; peristalsis esofágica; esfínter esofágico; trastornos de la deglución; inmunodeficiencia; autoinmunitario.

\footnotetext{
${ }^{1}$ Departamento de Gastroenterología.

2 Departamento de Inmunología.
}

Instituto Nacional de Pediatría, Ciudad de México

Received: 15 de September 2018

Accepted: 10 de April 2019

Correspondence

David Avelar Rodriguez

davidavelar1@outlook.com

This article should be cited as Avelar-Rodríguez D, Toro-Monjaraz EM, Peña-Vélez R, Yamazaki-Nakashimada MA, Ramírez-Mayans JA. A patient with esophageal achalasia and common variable immunodeficiency: A Case report and review of the literature. Acta Pediatr Mex. 2019;40(3):143-147. 


\section{BACKGROUND}

Esophageal achalasia is characterized by defective esophageal peristalsis and insufficient relaxation of the lower esophageal sphincter secondary to degeneration of the myenteric plexus. ${ }^{1}$ The exact pathophysiological mechanism through which the myenteric plexus is damaged is not fully understood, but increasing evidence suggests that autoimmunity, particularly anti-myenteric antibodies, may play a role., ${ }^{2,3,4}$ Autoimmunity is the second most common consequence of primary immunodeficiencies, ${ }^{5}$ which can manifests itself in a myriad of ways, such as autoimmune thyroiditis, anemia, Addison's disease, inflammatory bowel disease, vitiligo, and idiopathic thrombocytopenia, amongst others. ${ }^{6}$ To our knowledge, the association between primary immunodeficiencies and esophageal achalasia has not been reported in the literature.

Common variable immunodeficiency is a primary immunodeficiency syndrome characterized by decreased levels of IgA, IgE, and IgG (hypogammaglobulinemia), predisposing patients to severe and recurrent infections. ${ }^{6}$ Importantly, around $20 \%$ of patients with common variable immunodeficiency develop autoimmunity at some point of their lives. ${ }^{7}$ Thus, there is biological plausibility to the hypothesis that autoimmunity in the form of esophageal achalasia may play a role in common variable immunodeficiency. We present the case of an 18-year-old female with a history of common variable immunodeficiency and autoimmunity, who was diagnosed with type III achalasia by high-resolution esophageal manometry. Informed consent was obtained from the patient.

\section{CASE REPORT}

An 18-year-old female with a complex medical history of immunodeficiency and autoimmunity was referred to the pediatric gastroenterology motility unit for evaluation of rapidly progressive dysphagia, chest pain, and food regurgitation.
She had a history of alopecia, vitiligo, and autoimmune thyroiditis for 5 years of age, and at 13 years of age, she was diagnosed with common variable immunodeficiency based on hypogammaglobulinemia. In the interim since the common variable immunodeficiency diagnosis and the current presentation she developed autoimmune myopathy, multiple food allergies (milk, egg and soy), severe scoliosis (Figure 1), iron deficiency anemia, bronchiectasis, and constipation. In addition, during this time, she suffered from multiple complications secondary to the PID: peritonitis and sepsis secondary to complicated appendicitis; multiple episodes of bacterial pneumonia; an episode of knee septic arthritis; and one episode of intestinal obstruction, which required surgical intervention and was believed to be secondary to intestinal adhesions.

Prenatal, natal and postnatal periods were normal. She had a family history of unspecified muscular dystrophy in her brother, and rheumatoid arthritis in two aunts. Her parents were consanguineous (first cousins).

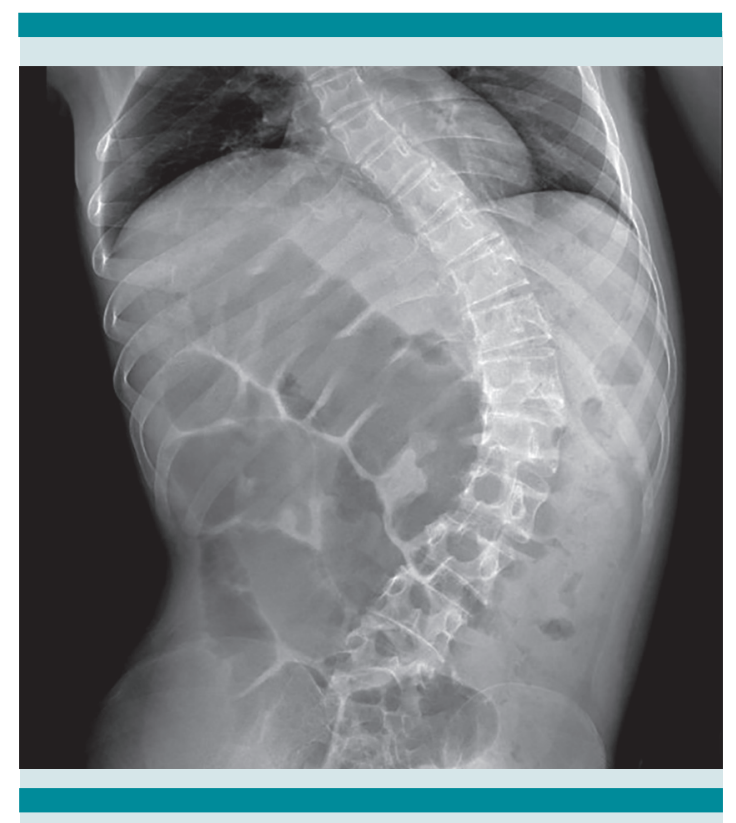

Figure 1. $\mathrm{X}$ ray showing severe scoliosis. 
She was being treated with deflazacort $(6 \mathrm{mg}$ three times a day), nandrolone (50 mg per week), methotrexate (10 mg per week), iron sulfate (200 $\mathrm{mg}$ a day), folic acid (5 mg biweekly), intravenous immunoglobulins (6.6 g per week), polyethylene glycol 3350, and nocturnal BiPAP.

4 months prior to presentation, she began complaining of dysphagia that rapidly progressed to liquids, retrosternal chest pain accompanied by the feeling of having food stuck in the throat, and food regurgitation. She denied vomiting or heartburn. She had been relieving the dysphagia and the chest pain by drinking water while swallowing.

Vital signs were normal and anthropometric data revealed underweight and stunted growth (weight: $26.7 \mathrm{~kg}$, < 3rd percentile; height: $137 \mathrm{~cm},<3 \mathrm{rd}$ percentile; BMI: 14.2, < 3rd percentile). Examination revealed generalized alopecia, multiple hypochromic lesions consistent with vitiligo, and severe scoliosis. Barium swallow showed the classic "bird beak" sign (Figure 2), and the high-resolution esophageal manometry (Figure 3) confirmed the diagnosis of type III esophageal achalasia based on the Chicago classification v3.0: integrated relaxation pressure $>30 \mathrm{mmHg}$, distal latency $<4.5 \mathrm{sec}$, and distal contraction integral $>8,000 \mathrm{mmHg} / \mathrm{sec} / \mathrm{cm}$. During the test, the patient had multiple episodes of retrosternal chest pain and regurgitation, which occurred alongside the esophageal spasms evidenced graphically.

The patient was scheduled for endoscopic injection of botulinum toxin; however, she developed immune thrombocytopenia, so the procedure was cancelled. A few months later, the patient died in an adult patient hospital - the exact cause of death is unknown.

\section{DISCUSSION}

To our knowledge, this is the first case report describing a patient diagnosed with common variable immunodeficiency and autoimmunity who develops achalasia. In addition to the possible association between common variable immunodeficiency, autoimmunity, and esophageal achalasia, the patient was diagnosed with type III esophageal achalasia, which is the least common subtype (10\%). ${ }^{2,8}$ According to the Chicago classification v3.0., type III esophageal achalasia (or spastic achalasia) is characterized by incomplete lower esophageal sphincter relaxation and premature contractions (Distal Latency $<4.5$ seconds) in at least $20 \%$ of swallows. ${ }^{9}$ The most common symptoms of type III esophageal achalasia are: dysphagia to solids (97\%) and liquids (80\%); regurgitation (79\%); chest pain $(61 \%)$; and weight loss $(22 \%) ;{ }^{8}$ all of which were present in our patient.

The degeneration of the myenteric plexus is the cornerstone of the pathophysiology of esophageal achalasia, which consequently leads to esophageal aperistalsis and impaired lower esophageal sphincter relaxation. ${ }^{10}$ We hypothe-

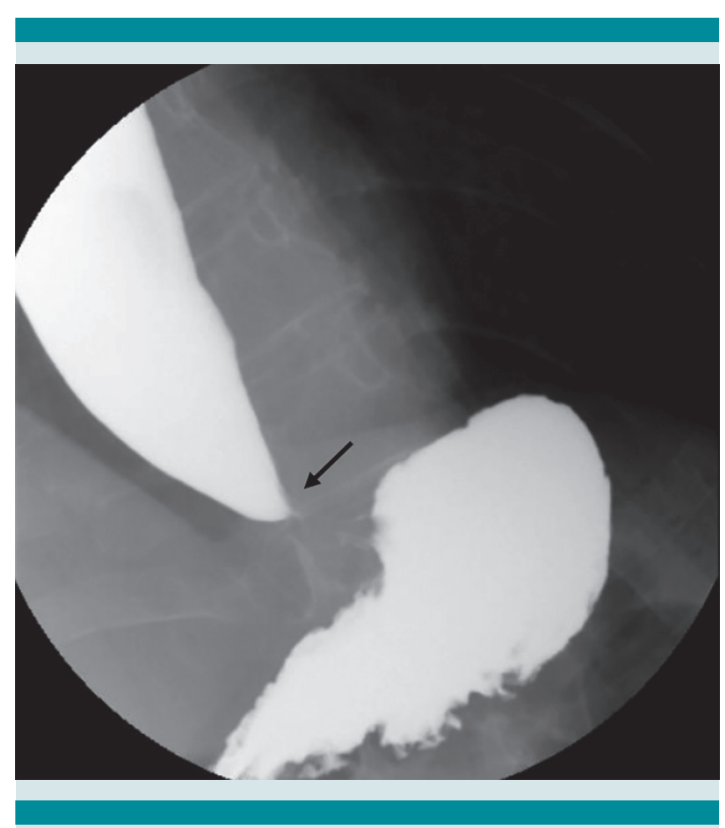

Figure 2. Barium swallow showing the classic "bird beak" sign (tapering of the distal esophagus; black arrow). 


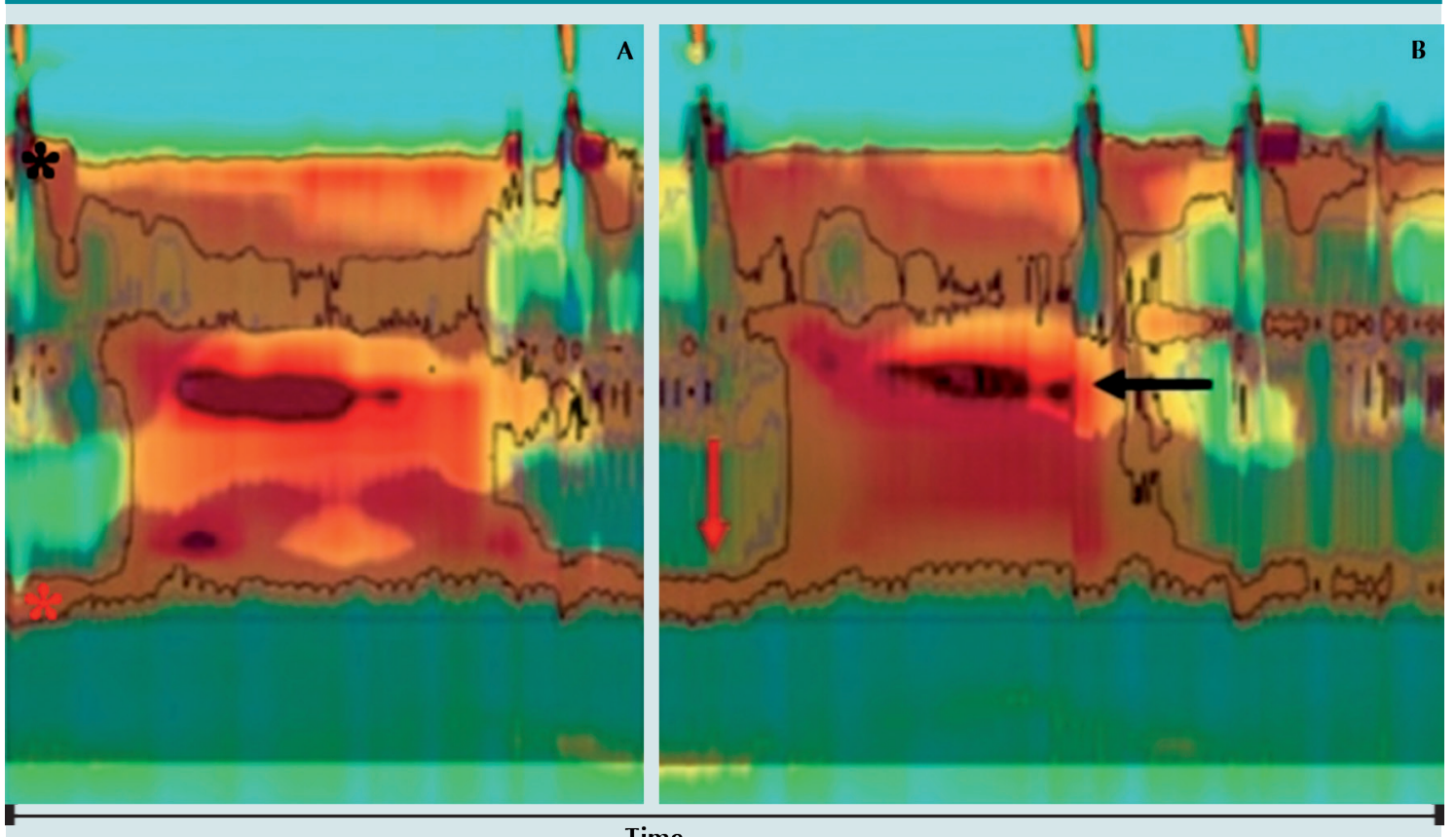

Time

Figure 3. High-resolution esophageal manometry plots of 2 different saline swallows. Panel A: the black asterisk indicates the upper esophageal sphincter, and the red asterisk indicates the lower esophageal sphincter. Panel B: note the premature contractions (black arrow) and the incomplete relaxation of the lower esophageal sphincter (red arrow). Also note how the esophagus fails to completely clear the liquid as assessed by impedance (shaded blue).

size that the degeneration of the myenteric plexus in our patient may be caused by her immune system overactivity, as evidenced by the multiple concomitant autoimmune diseases. More precisely, we believe that the presence of autoantibodies, such as anti-myenteric antibodies, might be damaging her esophageal myenteric plexus, thereby leading to achalasia (Figure 4). However, it is important to note that the proposed pathogenesis is mere speculation as we do not have any objective data (e.g., anti-myenteric titers or esophageal biopsies) to support it.

A recent observational, cross-sectional study of adult patients with esophageal achalasia from whom esophageal muscle biopsies were obtained, showed abundant perineural inflam- matory infiltrates as compared with control esophagostomies. In addition, $40 \%$ of patients with type III esophageal achalasia had a concomitant autoimmune disease and also showed the highest inflammatory response versus type I and II. ${ }^{4}$ This theory is also supported by one recent cross-sectional study ${ }^{2}$ that found a relative risk (RR) of 3.8 (95\% Cl 1.47-9.83) of autoimmunity in adult patients with achalasia as compared with age and sex-matched control patients with gastroesophageal reflux disease. Another crosssectional study ${ }^{4}$ found a similar RR of 3.6 (95\% $\mathrm{Cl}$ 2.5-5.3) of autoimmunity in patients with idiopathic achalasia. Furthermore, two aspects that support our theory are the fact that her symptoms developed in a relatively short period of time (4 months) - as opposed to adult patients 
with type III esophageal achalasia who often exhibit a disease trajectory of approximately 30 months; ${ }^{4}$ and the fact that the onset of dysphagia coincided with the onset of constipation, which may reflect the myenteric plexus damage by the immune system throughout the lower gastrointestinal tract.

This case report raises the question as to whether or not patients with PID and autoimmunity are at increased risk of developing esophageal achalasia. Given that $20 \%-90 \%$ of patients with PID develop autoimmunity ${ }^{7}$, it is important to evaluate this association.

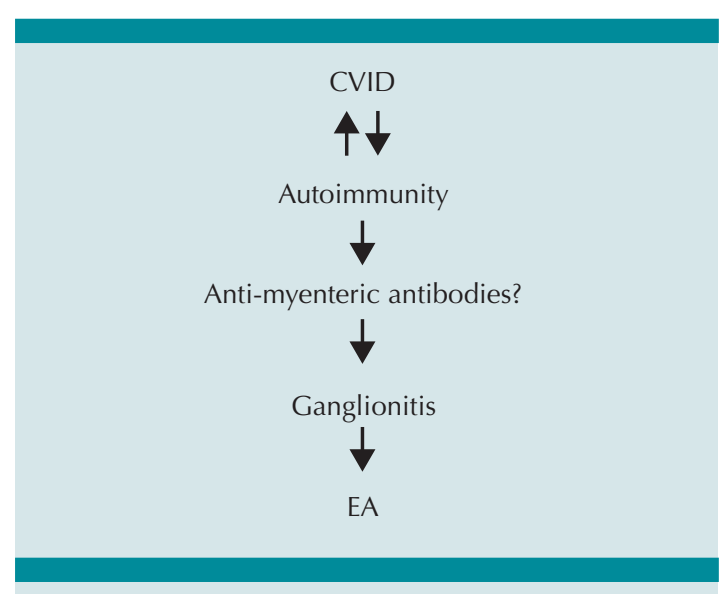

Figure 4. Proposed pathogensis of esophageal achalasia in our patient.

\section{REFERENCES}

1. Franklin AL. Childhood achalasia: A comprehensive review of disease, diagnosis and therapeutic management. World J Gastrointest Endosc [Internet]. 2014;6(4):105. http://www. wjgnet.com/1948-5190/full/v6/i4/105.htm

2. Romero-Hernández $\mathrm{F}$, et al. Autoimmune comorbidity in achalasia patients. J Gastroenterol Hepatol. 2018;33(1):203-8. https://doi.org/10.1111/jgh.13839

3. Booy JD, et al. The prevalence of autoimmune disease in patients with esophageal achalasia. Dis Esophagus. 2012;25(3):209-13. https://doi.org/10.1111/j.14422050.2011.01249.x

4. Furuzawa-Carballeda J, et al. Achalasia -An Autoimmune Inflammatory Disease: A Cross-Sectional Study. J Immunol Res. 2015;2015:1-18. http://www.hindawi.com/journals/ jir/2015/729217/

5. Azizi G, et al. Approach to the Management of Autoimmunity in Primary Immunodeficiency. Scand J Immunol. 2017 Jan;85(1):13-29. https://doi.org/10.1111/sji.12506

6. Schmidt RE, Grimbacher B, Witte T. Autoimmunity and primary immunodeficiency: Two sides of the same coin? Nat Rev Rheumatol [Internet]. 2018;14(1):7-18. http:// dx.doi.org/10.1038/nrrheum.2017.198

7. Dosanjh A. Autoimmunity and Immunodeficiency. Ped Rev [Internet]. 2015;36(11):489-95. http://pedsinreview.aappublications.org/content/36/11/489\%5Cnhttp://dx.doi. org/10.1542/pir.36-11-489

8. Hamer PW, et al. Type III achalasia -a clinical description. Dis Esophagus. 2017;(30):1-6.

9. Kahrilas PJ, et al. The Chicago Classification of esophageal motility disorders, v3.0. Neurogastroenterol Motil. 2015;27(2):160-74.

10. Boeckxstaens GE, et al. Achalasia. Lancet. 2014;383(9911):83-93. https://doi.org/10.1016/S01406736(13)60651-0 